\title{
How to mend a broken heart: a major stab wound of the left ventricle
}

\author{
Mari-Liis Kaljusto ${ }^{*}$ and Theis Tønnessen
}

\begin{abstract}
A 28-year-old male admitted with a stab wound under his left nipple, underwent emergency surgery because of confusion, a decreasing blood pressure and increasing tachycardia. A median sternotomy incision was made and after establishing cardiopulmonary bypass, a $7 \mathrm{~cm}$ wound in the left ventricle and a smaller wound in the left atrium were repaired. An injured segment of lung was resected and the left anterior descending and circumflex arteries were grafted after weaning from cardiopulmonary bypass was initially unsuccessful. Although the patient suffered a stroke, probably due to prehospital hypoperfusion, he eventually recovered without major sequelae. In addition to the case report we present a literature review of the last 15 years pertaining the management of penetrating cardiac injury.
\end{abstract}

\section{Background}

Onehundred and sixteen years ago Alex Cappelen repaired a penetrating injury of the left ventricle through a left anterior thoracotomy in Christiania (former name of Oslo), in one of the world's least violent countries [1]. Cappelen 's operation is considered to be the first report of a cardiac surgical procedure. Today trauma centers all over the world perform complex cardiac repairs due to penetrating trauma but the mortality is still high [2-5].

We report the case of a young man who suffered a large stab wound (SW) in the left ventricle and left atrium in addition to a lung injury for approximately 2 $\mathrm{h}$ before undergoing reparative surgery. In addition we present a literature review of penetrating cardiac injuries from 1997 - 2012 (Table 1). As data source we used all available English-language articles from peerreviewed journals in the Ovid MEDLINE and PubMed databases. The articles selected were relevant case reports, original articles and reviews focusing on the clinical presentation of penetrating cardiac injury, initial management, operative technique, complications and follow up.

\footnotetext{
* Correspondence: m.l.kaljusto@medisin.uio.no

Department of Cardiothoracic Surgery, Oslo University Hospital, Ullevål PB 4956 Nydalen and University of Oslo, Oslo, 0424, Norway
}

\section{Case presentation}

A 28-year-old male was admitted to the emergency department (ED) with a $5 \mathrm{~cm}$ stab wound (SW) under his left nipple. Pre-hospital treatment included insertion of a left chest drain due to dyspnoea, but this was clamped during transport because of massive hemorrhage. On admission, he was self-ventilating, with palpable carotid pulses, but without a measurable blood pressure. He was agitated and pale with a Glasgow coma score of 12 since he could open his eyes, localize pain and speak. The blood pressure ranged from $80 / 60$ to $100 / 60 \mathrm{mmHg}$ after starting intravenous fluid therapy and he had a tachycardia of $100-120$ beats per minute. When the clamp was removed from the chest drain, $650 \mathrm{ml}$ of blood was rapidly drained. The chest $\mathrm{x}$-ray showed persisting hemothorax and atelectasis and an additional drain was inserted. The arterial saturation varied from $86 \%$ to $98 \%$ and blood gas analysis showed a haemoglobin of $12.6 \mathrm{~g} / \mathrm{l}, \mathrm{pH} 7.17$, base excess -9 and lactate $5.5 \mathrm{mmol} / \mathrm{l}$. Focused Assessment with Sonography in Trauma (FAST) revealed no blood in the pericardium and upper abdomen. The neck veins were not distended and so the patient received transfusion of $1500 \mathrm{ml}$ of crystalloid fluid and $250 \mathrm{ml}$ of red cells. The blood pressure decreased as soon as the intravenous therapy was reduced, the tachycardia did not resolve and the patient was therefore transferred to the operating room.

After intubation, the ECG showed ST elevation and a median sternotomy incision was rapidly performed. The

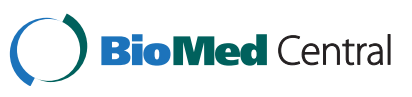


Table 1 Overview of the papers on penetrating cardiac injury from 1997 to 2012

\begin{tabular}{|c|c|c|}
\hline $\begin{array}{l}\text { Ref } n r \text {, author, year, } \\
\text { journal and study } \\
\text { origin. Study type }\end{array}$ & $\begin{array}{l}\text { Patients/patient } \\
\text { group/injury site }\end{array}$ & $\begin{array}{l}\text { Outcomes/performed } \\
\text { surgery }\end{array}$ \\
\hline $\begin{array}{l}\text { [2] Asensio et al. } \\
\text { (1998), J Trauma, } \\
\text { USA. Prospective } \\
\text { evaluation }\end{array}$ & $\begin{array}{l}\text { 2-year prospective } \\
\text { evaluation of } 105 \\
\text { penetrating cardiac } \\
\text { injuries }\end{array}$ & $\begin{array}{l}65 \% \text { GSW (survival } \\
16 \%), 35 \% \text { SW } \\
\text { (survival } 65 \% \text { ). EDT } \\
\text { in } 76 \text { pts with } 10 \\
\text { survivors (16\%) }\end{array}$ \\
\hline
\end{tabular}

Key results

Comments

[6] Baker et al.

(1998), Arch Surg,

USA. Retrospective study + review

$\begin{array}{ll}106 \text { pts with } & 6 \text { patients on CPB } \\ \text { penetrating heart } & \text { (4 gunshots, 2 stabs, } \\ \text { injury (1989-1995): } & \text { only 2 GSW survived) }\end{array}$

injury (1989-1995):

$60 \mathrm{GSW}, 46 \mathrm{SW}$,

$55 \%$ overall survival.

\author{
Presence of cardiac \\ tamponade and the \\ anatomical site did \\ not predict outcome, \\ presence of sinus \\ rythm when the \\ pericardium was \\ opened did \\ Few survivors due to \\ long time from \\ injury to CPB. \\ Those who were resuscitated $>5 \mathrm{~min}$ \\ prehospitally had a \\ very poor outcome. \\ SR at admission- \\ good prognostic \\ sign. CPB no good \\ to reverse outbled \\ situation/profound \\ shock, but necessary \\ to repair \\ multichamber \\ injuries/large \\ injuries \\ Mean interval \\ from injury to
}

[7] Bar et al. (2009),

Ind J Thorac

Cardiovasc Surg,

Israel. Retrospective

study

$\begin{array}{lll}14 \text { pts with } & 4 \text { sternotomies, } & \text { No CPB, 100\% } \\ \text { penetrating cardiac } & 10 \text { anterolat } & \text { survival, all } \\ \text { wound requiring } & \text { thoracotomies (8 with } & \text { discharged }\end{array}$
sternum transsection).

operation (1999-

2006) (9 SW, 2 GSW

5LV, 6RV, 3RA

and 2 schrapnel

injuries - all single

injuries, 1 multipl

chamber injuries, no

trauma)

combined.

[8] Barbosa et al.

(2011), Interact

Cardiovasc Thorac

18 yr male, SW

in 4th ic space in the

left midclavicular

Left thoracotomy,

suture of right

ventricular wound at

admittance

Developed

pneumonia/lung

edema postop, after

30 days AVR for

penetrated aortic

valve and closure of

shunt (RV -> aorta)

[9] Bowley et al

(2002), Ann Thorac

Surg, South Africa.

24 yr male, multiple stab wounds

No vital signs,

PEA,

at EDT: tamponade. $2 \mathrm{~cm}$

Initially Foley

catheter in the

wound, mattress

LV wound with

LAD transsection,

transsected PDA on

the opposite side (RV)

sutures, LAD

ligation, PDA

ligation. VF,

hypotension:

OPCAB with right

gastroepiploic artery.

Died of respiratory

complications due to

Brown-Sèquard

lesion (another stab

injury to the spinal

cord)

\begin{tabular}{ll}
\hline [10] Burack et al. & 207 pts with \\
(2007), & mediastinal \\
Ann Thorac & penetrating trauma \\
Surg, USA. & $1997-2003,72$ \\
Retrospective study & (35\%) unstable.
\end{tabular}
72 unstabel pts,
$15 \%$ had cardiac injury
with $18 \%$ survival
when explored in ED
and $71 \%$ when
reached $O R$

With penetrating

mediastinal trauma

the mortality is $85 \%$

when moribund at

arrival and 55\%

when unstable

(overall data, not

injury specific) 
Table 1 Overview of the papers on penetrating cardiac injury from 1997 to 2012 (Continued)

\begin{tabular}{lll}
\hline [11] Carr et al. & 2000-2009 & 28 SW with 17 \\
(2011), J Trauma, & penetrating cardiac & survivors (61\%), no \\
USA. Retrospective & injuries, both GSW & information about \\
study & and SW & anatomical site
\end{tabular}

Functional outcome

(5yrs) after: if

coronary arteries

were not involved -

good chance to

normal cardiac

function at follow up.

[12] Chughtai et al. (2002), Can J Surg,

Canada. Review +

Cases of 9 pts, $\quad$ Only 2 pts of the

8 managed with $\mathrm{CPB} \quad$ presented had a sole

in trauma setting cardiac injury (LV +

case report

from 1992-1998

coronary artery, RA + intrapericardial

The patient with LV

and coronary artey

injury died (no

vena cava)

without sequele

\section{[3] Clarke et al.}

(2011), J Thorac

Cardiovasc Surg,

South Africa.

All patients with

penetrating cardiac

Of 1062 stab wounds,

104 were operated,

injury requiring

76 had cardiac injury, overall mortality $10 \%$.

Retrospective study

$$
\text { 2006-2009 }
$$

Approx 50\% median sternotomy, 50\% left thoracotomy

When data put

together with

mortuary data:

mortality of $30 \%$ for

SW (in the mortuary

cohort of 548

patients with SW,

$38 \%$ had penetrating

cardiac injury). Less

than 25\% with

penetrating cardiac

injury reach hospital

alive, of these ca

90\% survive.

\begin{tabular}{lll}
\hline [13] Claassen et al. & 2 male pts : 21 yr & Pas 1: SW in \\
(2007), J Trauma, & and $27 \mathrm{yr}$ & 5 th right ic space (axilla) + \\
USA. Case report & & in abdomen), $400 \mathrm{ml}$ \\
& on chest tube + knife \\
& blade in thorax: \\
& laceration of right \\
& ventricular outflow \\
& tract (sutured) + lung \\
& resection
\end{tabular}

\section{Pas 2: SW in left}

supraclav midline.

Tamponade at

FAST: pericardial

drainage, thereafter

stable. Sternotomy

after transfer,

laceration of the

pulmonary

outflow tract, sutured,

further repaire of

aortopulmonary

shunt (thrill + TEE)

\begin{tabular}{ll}
\hline [14] Comoglio et al. & 75 yr male with chest \\
(2010), Int J Emerg Med, & pain and syncope, \\
Italy. Case & had been working \\
report & with a nailgun
\end{tabular}

Stable, underwent CT where the nailgun nail was found imbedded

The pt underwent

formal coronary angiography to rule in the left ventricular out underlying wall. Removed through median coronary disease sternotomy, suture without $C P B$

\begin{tabular}{|c|c|c|c|}
\hline $\begin{array}{l}\text { [15] Desai et al. } \\
\text { (2008), J Thorac } \\
\text { Cardiovasc Surg, } \\
\text { Canada. Brief } \\
\text { communication }\end{array}$ & $\begin{array}{l}22 \mathrm{yr} \text { male, single } \\
\text { SW in the left chest }\end{array}$ & $\begin{array}{l}\text { Severe shock, loss of } \\
\text { vital signs in the ED. } \\
\text { EDT, ROSC after } \\
\text { opening of } \\
\text { pericardium. } \\
\text { Tamponde + through- } \\
\text { and-through } \\
\text { laceration of the RV, } \\
\text { stapled and } \\
\text { transferred to OR }\end{array}$ & $\begin{array}{l}\text { CPB, staples had } \\
\text { occluded the PDA, } \\
\text { the wound in close } \\
\text { proximity. Staples } \\
\text { removed, wound } \\
\text { sutured. } \\
\text { Intraoperative } \\
\text { fluorescence } \\
\text { coronary } \\
\text { angiography showed } \\
\text { widely patent PDA }\end{array}$ \\
\hline $\begin{array}{l}\text { [16] Fedalen et al. } \\
\text { (2001), J Trauma, } \\
\text { USA. Case } \\
\text { report }\end{array}$ & $\begin{array}{l}30 \mathrm{yr} \text { male, isolated } \\
\text { SW to left anterior } \\
\text { chest wall }\end{array}$ & $\begin{array}{l}\text { Tension } \\
\text { pneumothorax, } \\
\text { hypotension, cardiac } \\
\text { tamponade. } \\
\text { Transfer to OR }\end{array}$ & $\begin{array}{l}\text { Median sternotomy, } \\
\text { proximal laceration } \\
\text { of LAD with } \\
\text { posterior wall of the } \\
\text { vessel intact. } \\
\text { OPCAB with SVG, } \\
\text { intraluminal shunt. } \\
\text { Laceration used as }\end{array}$ \\
\hline
\end{tabular}


Table 1 Overview of the papers on penetrating cardiac injury from 1997 to 2012 (Continued)

\begin{tabular}{|c|c|c|c|}
\hline & & & $\begin{array}{l}\text { anastomotic site. } \\
\text { Discharge at postop } \\
\text { day } 8\end{array}$ \\
\hline $\begin{array}{l}\text { [17] Fulton et al. } \\
\text { (1997), Ann Thorac } \\
\text { Surg, South Africa. } \\
\text { Case report }\end{array}$ & $\begin{array}{l}61 \text { yr male, a single } \\
\text { SW in right } 2 \text { nd ic } \\
\text { space parasternally. } \\
\text { History of right-sided } \\
\text { empyema } 18 \text { yrs ago } \\
\text { treated by } \\
\text { thoracotomy and } \\
\text { decortication }\end{array}$ & $\begin{array}{l}\text { Stable, enlargened } \\
\text { mediastinum at chest } \\
\text { X-ray. Arcography } \\
\text { showed laceration to } \\
\text { innominate artery, left } \\
\text { common carotid } \\
\text { artery and left } \\
\text { subclavian artery. } \\
\text { Distal cannulation, } \\
\text { repair in deep } \\
\text { hypothermic arrest }\end{array}$ & $\begin{array}{l}\text { Uneventful } \\
\text { postoperatively, } \\
\text { discharge at day } 10\end{array}$ \\
\hline $\begin{array}{l}\text { [18] Hibino et al. } \\
\text { (2003), Journal of } \\
\text { Cardiac Surgery, } \\
\text { Japan. Case report }\end{array}$ & $\begin{array}{l}39 \text { yr male, SW } \\
\text { anterior chest wall, } \\
\text { suicide attempt. }\end{array}$ & $\begin{array}{l}\text { Median sternotomy at } \\
\text { OR. Injury of the right } \\
\text { ventricular outflow } \\
\text { tract, repair without } \\
\text { CPB }\end{array}$ & $\begin{array}{l}2 \text { yr after aorto-right } \\
\text { ventricular fistula } \\
\text { (dyspnea), repair } \\
\text { with patch and AVR. } \\
\text { The authors suggest } \\
\text { long term follow-up } \\
\text { to detect } \\
\text { unindentified lesions }\end{array}$ \\
\hline $\begin{array}{l}\text { [19] Ito et al. (2009), } \\
\text { Gen Thorac } \\
\text { Cardiovasc Surg, } \\
\text { Japan. Case report }\end{array}$ & $\begin{array}{l}51 \text { yr male, SW in } \\
\text { left } 5 \text { th ic space with } \\
\text { the ice pick still in } \\
\text { place, suicidal } \\
\text { attempt }\end{array}$ & $\begin{array}{l}\text { Ice pick was moving } \\
\text { synchronously with } \\
\text { heart beat, echo } \\
\text { showed tip in right } \\
\text { ventricle, cardiac } \\
\text { tamponade }\end{array}$ & $\begin{array}{l}\text { CPB, mattress stich. } \\
\text { Heart murmur day } \\
12,5 \mathrm{~mm} \text { ventricular } \\
\text { septal defect } \\
\text { detected. No } \\
\text { surgery, follow up }\end{array}$ \\
\hline $\begin{array}{l}\text { [20] Jodati et al. } \\
\text { (2011), Interact } \\
\text { Cardiovasc Thorac } \\
\text { Surg, Iran. Case } \\
\text { report }\end{array}$ & $\begin{array}{l}24 \text { yr construction } \\
\text { worker, shortness of } \\
\text { breath and } \\
\text { palpitations, unaware } \\
\text { of the pneumatic } \\
\text { nailgun injury }\end{array}$ & $\begin{array}{l}\text { Nail through RV } \\
\text { outflow tract, } \\
\text { interventricular } \\
\text { septum, through the } \\
\text { mitral valve at TEE } \\
\text { and CT. }\end{array}$ & $\begin{array}{l}\text { Median sternotomy, } \\
\text { CPB. Entry point on } \\
\text { RV, nail tip barely } \\
\text { visible, not exit } \\
\text { wound after LA was } \\
\text { opened. Nail } \\
\text { removed, anterior } \\
\text { leaflet of mitral } \\
\text { valve repaired. } \\
\text { Discharge at postop } \\
\text { day } 5\end{array}$ \\
\hline $\begin{array}{l}\text { [21] Kang et al. } \\
\text { (2009), Injury, New } \\
\text { Zealand/Canada. } \\
\text { Review }\end{array}$ & $\begin{array}{l}\text { Review about causes } \\
\text { of penetrating cardiac } \\
\text { injury, } \\
\text { pathophysiology, } \\
\text { sequelae, initial and } \\
\text { operative } \\
\text { management }\end{array}$ & $\begin{array}{l}\text { Hihglighted key } \\
\text { points for every } \\
\text { section, outlining of } \\
\text { prognostic factors }\end{array}$ & $\begin{array}{l}\text { Few other } \\
\text { conditions in } \\
\text { medicine are as } \\
\text { lethal; death occurs } \\
\text { from cardiac } \\
\text { tamponade or } \\
\text { exsanguination; the } \\
\text { greatest danger is } \\
\text { missing the dgn; } \\
\text { resuscitation is of } \\
\text { limited value; } \\
\text { immediate operative } \\
\text { intervention is the } \\
\text { only meaningful } \\
\text { treatment }\end{array}$ \\
\hline $\begin{array}{l}\text { [22] Karin et al. } \\
\text { (2001), Eur J Emerg } \\
\text { Med, Israel. Case } \\
\text { report and literature } \\
\text { review }\end{array}$ & $\begin{array}{l}\text { 1. } 29 \text { yr male with } \\
\text { single SW in left } \\
\text { chest. } 2.35 \text { yr male, } \\
\text { stabbed in left lower } \\
\text { thorax }\end{array}$ & $\begin{array}{l}\text { 1. Cardiac tamponade, } \\
\text { ED thoracotomy: SW } \\
\text { in the LV transsecting } \\
\text { LAD (ligated, } \\
\text { sutured). CPB with } \\
\text { SVG in OR 2. } \\
\text { Hemopneumothorax, } \\
\text { respiratory distress, } \\
\text { chest tubes. FAST: } \\
\text { tamponade. Left } \\
\text { thoracotmy at OR, } \\
\text { distal LAD } \\
\text { transsection, ligated. }\end{array}$ & $\begin{array}{l}\text { Both had normal } \\
\text { echocardiographies } \\
\text { postoperatively and } \\
\text { were discharged } \\
\text { respectively 10th } \\
\text { and 7th postop day }\end{array}$ \\
\hline
\end{tabular}




\section{Table 1 Overview of the papers on penetrating cardiac injury from 1997 to 2012 (Continued)}

\begin{tabular}{ll}
\hline [23] Kurimoto et al. & $57 \mathrm{yr}$ male, SW in \\
(2007), Surgery & 5th ic space \\
today, Japan. Case & parasternally, suicide \\
report & attempt
\end{tabular}
report
Arrest prehospitally,
EDT at admission +

pericardiotomy,

further percutaneous

$\mathrm{CPB}+$ repair at ED. $3 \mathrm{~cm}$

left ventricular

wound near coronary

artery

\begin{tabular}{ll}
\hline [24] Lau et al. & $31 \mathrm{yr}$ male, 2 SW: in \\
(2008), Singapore & the left 4th ic space \\
Med J. Case report & and in the right 2nd \\
& ic space
\end{tabular}

Pulseless with PEA,

EDT, SW in the RV, internal cardiac massage to ROSC, transfer to the OR. Suture of the laceration

\section{[4] Molina et al.}

(2008), Interact

Cardiovasc Thorac

Surg, USA.

Retrospective study
237 pts (2000-2006)

with EDT for

penetrating injury, of

these 94 with

penetrating

cardiac injury

\section{GSW 87\%, SW 13\%}

overall survival $8 \%$

(5\% for GSW, 33\% for SW)
Postop

encephalopathy, 3 yrs

afterwards at

rehabilitation home
[25] Moore et al. (2007), Am Surg,

USA. Case report
16 yr male, multiple stab wounds
Tachycardia and hypotension, left hemothorax. FAST: pericardial and infraabdominal fluid. LAD injury (ligation), RV (suture).

Pt admitted 3 days
after hunting with arrow in the midline. Attempted retracted at local hospital, referred to the visiting cardiothoracic team from USA. TTE: arrow through right ventricle, ventricular septal shunt

$\begin{array}{ll}\text { None of the patients } & \text { Mostly GSW } \\ \text { who reached OR } & \text {-very poor } \\ \text { needed CPB. } & \text { outcome }\end{array}$

Discharged to further rehabilitation due to hypoxic encephalopathy

26] Nwiloh et al. Surg, USA/Nigeria. $11 \mathrm{yr}$ boy, arrow in
the 4th ic space

Predictors of rythm, signs of life at ED, SW vs GSW, transport by police, higher GCS

OPCAB (SVG) due

to evolving large anteroseptal Ml. Abdominal packing.

Discharge postop day 17.

\section{$\mathrm{CPB}$, retraction of} the arrow and suture of the RV. Shunt was insignificant, not repaired outcome

Case report

\begin{tabular}{ll}
\hline [27] O'Connor et al. & History, \\
(2009), J R Army & demographics and \\
Med Corps, USA. & outcome, repair \\
Review & techniques, special \\
& occasions etc.
\end{tabular}

ran

Refer to iv adenosin infusion for temporary arrest to facilitate the repair

[28] Parra et al. (2010), J Thorac Cardiovasc Surg, USA. Case report
81 yr male struck by a stingray in his left chest

$C T$ : left
pneumothorax,
foreign body through
mediastinum. Left
anterior thoracotomy
at the OR, the barb
was found imbedded
in the heart, the entry
was repaired and pt
transferred to a
cardiac center

CT: left foreign body through mediastinum. Left anterior thoracotomy was found imbedded cardiac center

\begin{tabular}{|c|c|}
\hline $\begin{array}{l}\text { At cardiac center: } \\
\text { CPB, barb through } \\
\text { both right and left } \\
\text { ventricles. RA was } \\
\text { accessed and the } \\
\text { barb pulled out in an } \\
\text { antegrade fashion. } \\
\text { Ventricular septal } \\
\text { and RV defects } \\
\text { closed with } \\
\text { pledgeted sutures. } \\
\text { Discharge } 60 \text { days } \\
\text { postop }\end{array}$ & $\begin{array}{l}\text { Splenectomy } \\
\text { due to } \\
\text { hemorrhage } \\
\text { postop day } 1 \\
\text { (unidentified } \\
\text { injury, the pt } \\
\text { fell when } \\
\text { attacked by } \\
\text { the sting ray) }\end{array}$ \\
\hline $\begin{array}{l}\text { Predictors of } \\
\text { survival in } \\
\text { multivariate }\end{array}$ & $\begin{array}{l}\text { Multiple } \\
\text { GSW almost } \\
\text { unsalvagable }\end{array}$ \\
\hline
\end{tabular}

\begin{tabular}{|c|c|c|c|c|}
\hline $\begin{array}{l}\text { [29] Seamon et al. } \\
\text { (2009), J Trauma, } \\
\text { USA. Retrospective } \\
\text { study }\end{array}$ & $\begin{array}{l}283 \text { pts with cardiac } \\
\text { or great vessel } \\
\text { penetrating injury }\end{array}$ & $\begin{array}{l}88 \% \text { GSW (survival } \\
2,8 \%), 12 \% \text { SW } \\
\text { (survival } 24,2 \% \text { ) }\end{array}$ & $\begin{array}{l}\text { Predictors of } \\
\text { survival in } \\
\text { multivariate }\end{array}$ & $\begin{array}{l}\text { Multiple } \\
\text { GSW almost } \\
\text { unsalvagable }\end{array}$ \\
\hline
\end{tabular}


Table 1 Overview of the papers on penetrating cardiac injury from 1997 to 2012 (Continued)

\begin{tabular}{|c|c|c|c|}
\hline & $\begin{array}{l}\text { requiring EDT } \\
(2000-2007)\end{array}$ & & $\begin{array}{l}\text { analysis: GSW and } \\
\text { GCS }\end{array}$ \\
\hline $\begin{array}{l}\text { [30] Sugiyama et al. } \\
\text { (2011), Ann Thorac } \\
\text { Surg, USA. } \\
\text { Case report }\end{array}$ & $\begin{array}{l}20 \text { yr male, SW in } \\
\text { left chest } \\
\text { (nipple level) }\end{array}$ & $\begin{array}{l}\text { Cardiac arrest at ED, } \\
\text { left anterior } \\
\text { thoracotomy, suture of } \\
\text { right ventricle }\end{array}$ & $\begin{array}{l}\text { Postop instable, } 7 \text {. } \\
\text { day - } 1,9 \mathrm{~cm} \text { septal } \\
\text { defect with left to } \\
\text { right shunt }(3,7-1) \text {, } \\
\text { ARDS etc., } \\
\text { shunt=VSD repaired } \\
2 \text { mnths afterwards }\end{array}$ \\
\hline $\begin{array}{l}\text { [5] Tang et al. } \\
(2011), \\
\text { Arch Surg, USA. } \\
\text { Retrospective study }\end{array}$ & $\begin{array}{l}406 \text { pts with } \\
\text { penetrating cardiac } \\
\text { injury from } \\
2000-2010\end{array}$ & $\begin{array}{l}74 \% \text { SW, } 26 \% \text { GSW. } \\
\text { Overall survival 27\%. }\end{array}$ & $\begin{array}{l}\text { Focusses on } \\
\text { postdischarge } \\
\text { complications, 17\% } \\
\text { had an abnormal } \\
\text { echocardiogram at } \\
\text { follow-up; all } \\
\text { managed } \\
\text { conservatively }\end{array}$ \\
\hline $\begin{array}{l}\text { [31] Tasdemir et al. } \\
\text { (2011), Acta Cardiol, } \\
\text { Turkey. Case report }\end{array}$ & $\begin{array}{l}19 \text { yr male, SW left } \\
\text { chest }\end{array}$ & $\begin{array}{l}\text { Presented in shock, } \\
\text { tamponade and } \\
\text { complete bilat visual } \\
\text { loss. SW of LV with } \\
\text { LAD injury, }\end{array}$ & $\begin{array}{l}\text { CPB, SV graft to } \\
\text { LAD, visus } \\
\text { gradually regained }\end{array}$ \\
\hline $\begin{array}{l}\text { [32] Toda et al. } \\
\text { (2007), Interact } \\
\text { Cardiovasc Thor } \\
\text { Surg, Japan. Case } \\
\text { report }\end{array}$ & $\begin{array}{l}50 \mathrm{yr} \text { male, } 3 \text { SW by } \\
30 \mathrm{~cm} \text { sashimi knife, } \\
\text { (Neck, 4th ic space, } \\
\text { right upper quadrant } \\
\text { of abdomen), suicidal } \\
\text { attempt }\end{array}$ & $\begin{array}{l}\text { Hypotensive, FAST } \\
\text { negative, CT showed } \\
\text { pneumopericardium } \\
\text { and left hemothorax }\end{array}$ & $\begin{array}{l}\text { Median sternotomy, } \\
\text { RV laceration, repair } \\
\text { by pledgeted } \\
\text { sutures. LV } \\
\text { laceration near } \\
\text { posterolateral branch } \\
\text { of CX, without } \\
\text { bleeding, covered } \\
\text { with TachoComb. }\end{array}$ \\
\hline $\begin{array}{l}\text { [33] Topal et al. } \\
\text { (2010), J Trauma, } \\
\text { Turkey. } \\
\text { Retrospective study }\end{array}$ & $\begin{array}{l}\text { Penetrating cardiac } \\
\text { injury (57 SW, } 4 \text { GSW), } \\
2002-2009\end{array}$ & $\begin{array}{l}53 \text { left thoracotomies, } \\
4 \text { median } \\
\text { sternotomies. } 2 \text { LAD } \\
\text { injuries, ligated. Total } \\
\text { mortality 15\% } \\
\text { (isolated RV }-11 \% \text {, } \\
\text { isolated LV } 31 \% \\
\text { (mixed SW and } \\
\text { GSW). }\end{array}$ & $\begin{array}{l}95 \% \text { injury in } \\
1 \text { chamber. Focusses } \\
\text { on predictors of } \\
\text { outcome: }> \\
\text { mortality when } \\
\text { uncouncious, } \\
\mathrm{BP}<50 \text {, low Hct, Na, } \\
\text { temp and } \mathrm{PH} \text {. } \\
\text { Patients pronounced } \\
\text { "dead on arrival" } \\
\text { were not assessed in } \\
\text { this study. }\end{array}$ \\
\hline $\begin{array}{l}\text { [34] Topaloglu et al. } \\
\text { (2006), Tex Heart } \\
\text { Inst J, Turkey. Case } \\
\text { report }\end{array}$ & $\begin{array}{l}19 \text { yr male, SW with } \\
\text { skrewdriver in } 5 \text { th } \\
\text { left ic space }\end{array}$ & $\begin{array}{l}\text { Dyspnea and } \\
\text { hypotension, } 1500 \mathrm{ml} \\
\text { chest tube output. Left } \\
\text { anterior thoracotomy } \\
\text { at OR, RV wound } \\
\text { repair. }\end{array}$ & $\begin{array}{l}1 \text { week later a } \\
\text { cardiac murmur } \\
\text { occurred, transfer to } \\
\text { a cardiac center, } \\
\text { TTE: perforation of } \\
\text { membranous septum } \\
\text { and anterior leaflet } \\
\text { of the mitral valve. } \\
\text { Median sternotomy, } \\
\text { CPB, LA access: } \\
\text { pericardial patch } \\
\text { repair of the leaflet, } \\
\text { suture of the septal } \\
\text { defect through RA. } \\
\text { Discharged postop } \\
\text { day } 5 \text {. }\end{array}$ \\
\hline $\begin{array}{l}\text { [35] Topcuoglu et al. } \\
\text { (2009), Thorac } \\
\text { Cardiovasc Surg, } \\
\text { Turkey. Case report }\end{array}$ & $\begin{array}{l}14 \text { yr male, SW in } \\
\text { right 6th icr } \\
\text { paravertebrally, } \\
\text { stable with knife } \\
\text { in place }\end{array}$ & $\begin{array}{l}\text { Right posterolat } \\
\text { thoracotomy (knife } \\
\text { in situ), at removal } \\
\text { bleeding from atrio- } \\
\text { inferiocaval junction }\end{array}$ & $\begin{array}{l}\text { Repair on CPB, } \\
\text { discharged on 7th } \\
\text { postop day }\end{array}$ \\
\hline
\end{tabular}


Table 1 Overview of the papers on penetrating cardiac injury from 1997 to 2012 (Continued)

\begin{tabular}{|c|c|c|c|c|}
\hline $\begin{array}{l}\text { [36] Gwely et al. } \\
\text { (2010), Thorac } \\
\text { Cardiovasc Surg, } \\
\text { Egypt. } \\
\text { Retrospective study }\end{array}$ & $\begin{array}{l}73 \text { pts operated for } \\
\text { cardiac SW } \\
\text { (1998-2008) }\end{array}$ & $\begin{array}{l}\text { Unstable } 35 \%, 20 \% \\
\text { cardiac arrest prior to } \\
\text { EDT. Mortality } 23 \%\end{array}$ & $\begin{array}{l}\text { Poor prognosis: } \\
\text { cardiopulmonary } \\
\text { resuscitation } \\
\text { (mortality rate } 68 \%) \text {, } \\
\text { EDT }(67 \%) \text { and } \\
\text { shock }(50 \%) \text { on } \\
\text { admission }\end{array}$ & $\begin{array}{l}\text { Dead on } \\
\text { arrival } \\
\text { excluded }\end{array}$ \\
\hline
\end{tabular}

AVR - aortic valve replacement, CABG - coronary artery bypass, CPB - cardiopulmonary bypass, CX - circumflex artery, ED - emergency department, EDT - emergency department thoracotomy, FAST - focused assessment with sonography in trauma, GCS - Glasgow coma scale, GSW - gunshot wound, LA - left atrium, LAD - left anterior descendent artery, LV - left ventricle, OPCAB - off pump coronary artery bypass, OR - operating room, PDA - posterior descendent artery, RA - right atrium, ROSC - return of spontaneous circulation, RV - right ventricle, SVG - saphenous vein graft, TEE - transesophaegeal echocardiography, $\mathrm{VF}$ - ventricular fibrillation.

pericardium was opened and although there was a clot ventral to the heart, there were no signs of cardiac tamponade. There was a $6 \mathrm{~cm}$ cut in the lateral pericardium corresponding to the stab wound in the chest and a $7 \mathrm{~cm}$, almost transmural wound in the left ventricle, parallel to a major diagonal branch (Figure 1). The wound was not bleeding. A $5 \mathrm{~cm}$ stab wound in the left lung (Figure 2) was sutured and cardiopulmonary bypass $(\mathrm{CPB})$ was established. The cardiac injury ended close to the origin of the left main stem and crossed the left atrium. The ventricular wound was repaired with single mattress sutures reinforced by strips of bovine pericardium (Figures 3, 4) without arresting the heart and without cross-clamping the aorta. The left atrium was sutured using 5/0 Prolene (Ethicon). Blood appeared in the tracheal tube and bronchoscopy revealed ongoing bleeding from the left lung which required resection of the lingula. Weaning from CPB was initially unsuccessful and we suspected that there had been injury to the left

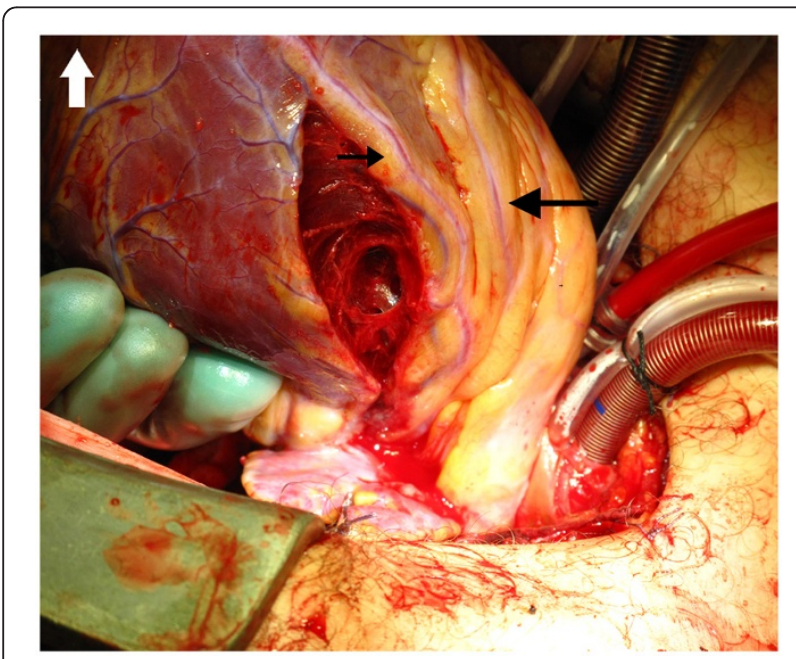

Figure 1 The left ventricular injury almost penetrating the left ventricular wall, notice the left anterior descending coronary artery (large black arrow) with the first diagonal branch (small black arrow). All the photos are taken from the anaesthesiologist point of view and the white arrow indicates the caudal direction. main stem either caused by the initial stab or by the hemostatic sutures. The left anterior descending artery was grafted using the internal mammary artery and a vein graft was anastomosed to the circumflex artery. The patient was thereafter successfully weaned from CPB.

Post-operatively, the patient had signs of a stroke and a CT scan revealed a cerebral infarction. One week after surgery he was transferred to the neurological intensive care unit. After three weeks he was awake and self-ventilating. He was moved to his local hospital and was discharged after 6 weeks with only a minor deficit affecting the left upper extremity.

\section{Discussion}

We report the case of a young male patient with a major cardiac stab wound combined with lung injury. Our patient was stabbed during a violent quarrel, thus being a typical stab victim, however, in Japan suicide attempts seem to be equally frequent $[18,23]$. In large series, gunshot wounds (GSW) are the predominant cause of cardiac penetrating trauma $[2,4,6,29]$. In Norway, this type of injury is obviously less common but still existing [37-39].

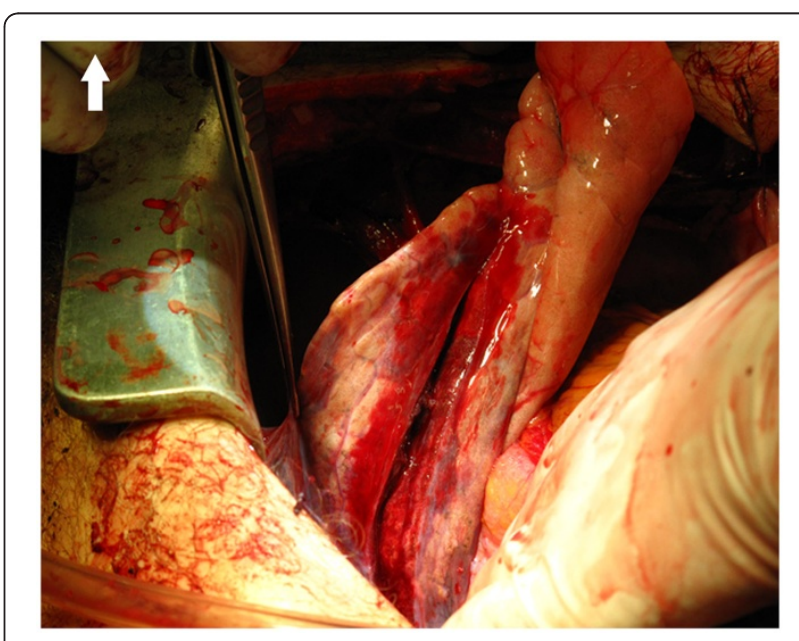

Figure $\mathbf{2}$ The injured left lung (upper lobe, lingula). 


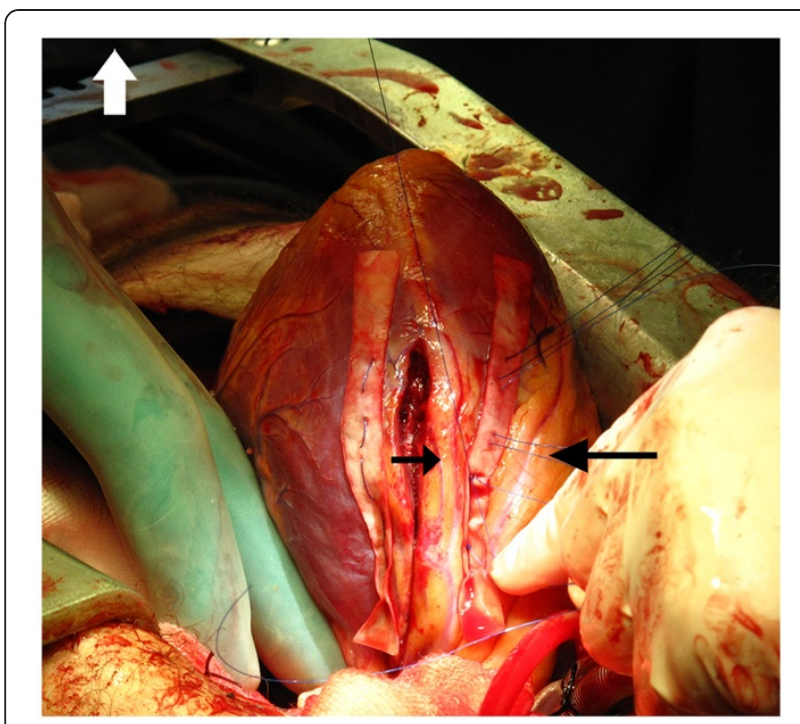

Figure 3 The wound repair with bovine pericardial strips.

Knife is the most common weapon for stab injuries, followed by other sharp items such as screwdrivers [34], ice picks [19], chopsticks, pneumatic nailgun nails [14,20,40] but also curiosities as barb from a sting ray [28]. Fractured ribs or sternum are also reported to cause cardiac penetration [41]. Pneumatic nails might be shot without the patient noticing and cause surprise when detected by CT scan or eccocardiography imbedded in the heart $[14,20]$. The iatrogenic penetrations of the heart due to different medical devices (pacemaker leads, intracoronary stents, Amplatzer devices) are not discussed in this paper.

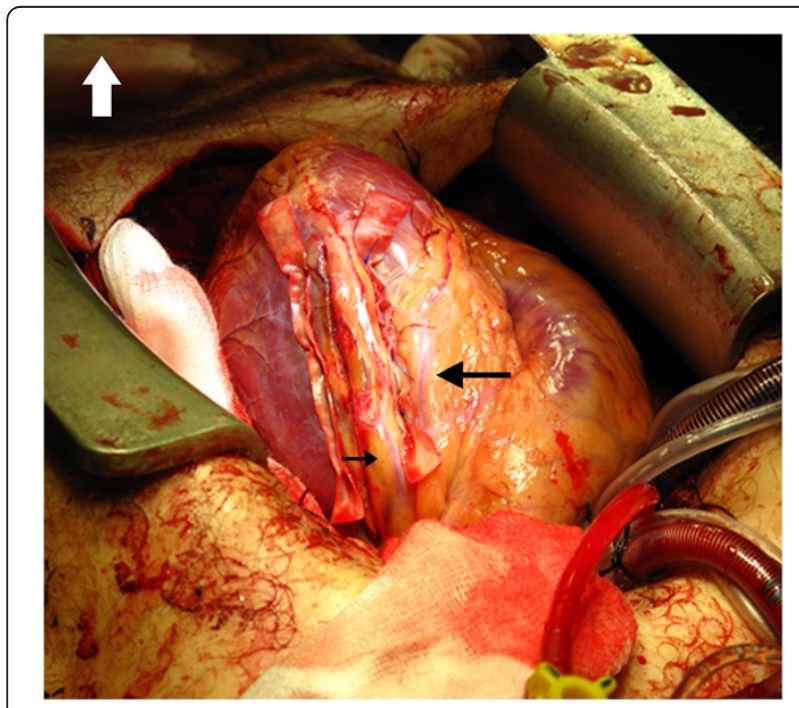

Figure 4 The completed repair of the left ventricular wound.
Penetrating cardiac wounds are mostly fatal either due to cardiac tamponade, exsanguination or coronary artery injury [1]. Clarke reports that of 1064 patients with stab wounds to the chest 104 were operated and 76 were found to have a cardiac injury [3]. The overall mortality was $10 \%$ giving an impression of low mortality in this particular group of cardiac injuries. However, when the data was put together with the mortuary report for the same time, the mortality for penetrating cardiac stab wounds was found to be $30 \%$. Most of the studies are retrospective and the patient selection is determined by the survivors arriving at the hospital and ignorance of the mortuary data. Topal et al. report a mortality rate of $15 \%$ in 61 penetrating cardiac cases with predominantly stab wounds but state that "patients pronounced dead on arrival were not assessed in this study" [33]. The only known prospective study reports another reality with a mortality rate of $97 \%$ when multichamber penetrating injury is present [2]. Also Molina et al. reports high mortality (67\%) in a cohort with mainly stab wounds throughout the last decennium [4].

Our patient maintained suboptimal circulation for approximately two hours before undergoing surgery. The time span taken into consideration, our patient was extremely lucky as the outcome is usually poor when the time from trauma to surgery increases $[5,6]$. An Israeli study of 14 patients reports $100 \%$ survival (9 SW, 2 GSW, 1 shrapnel injury and 1 multi trauma) with the mean time from injury to surgery of $37 \mathrm{~min}$ [7]. In addition to fast admission to surgery, this outstanding result may also be due to the fact that all patients had single chamber injuries and no coronary artery injury. According to Burack et al., patients with penetrating mediastinal trauma triage themselves between operative intervention or evaluation and observation as they present either stable or unstable on admission. In this retrospective study the authors present 207 patients of which 72 were unstable [10]. Of these $15 \%$ had cardiac injury with $18 \%$ survival when explored in the ED. The survival rate was $71 \%$ when patients with penetrating cardiac injury reached the operating room. All patients having cardiac injury in this study were unstable (authors criteria: traumatic cardiac arrest or near arrest and an emergency department thoracotomy (EDT); cardiac tamponade; ATLS grad III shock despite fluid resuscitation; chest tube output $>1500 \mathrm{ml}$ at insertion; chest tube output $>500 \mathrm{ml}$ in the initial hour; massive hemothorax after chest tube input). The study does not report the use of $\mathrm{CPB}$.

In our patient, there was a large stab wound of the left ventricle running parallel to the diagonal artery as well as a stab wound in the left atrium. Regarding the location of penetrating cardiac injury, the right ventricle is the most common due to its ventral anatomical position, 
followed by the left ventricle, right atrium and left atrium $[2,3,11]$. The patients with a single right ventricle injury are mostly salvagable whereas those with multichamber injuries have a very high mortality $[2,4,21]$. The concomitant injury of the lung in our patient is not a rarity [3]. Our patient did not suffer from cardiac tamponade as there was a large opening to the left pleural cavity through the wound in the pericardium. This probably saved his life, although profound hypovolemia can conceal signs of cardiac tamponade leading to delayed diagnosis [36]. However, cardiac tamponade in the reviewed studies is not a prognostic factor regarding survival $[2,33]$.

The role of CPB has been debated in trauma surgery, espescially when it comes to penetrating cardiac wounds $[6,21]$. Some series present large cohorts of penetrating cardiac injury without use of CPB [3-5]. In case of complex cardiac injuries with multichamber lacerations the advantages of a bloodless and still operating field is obvious $[6,20,21]$. The required heparinisation for CPB might be deleterious in a trauma patient. However, if the bleeding source or sources can be controlled, the risk of further profound haemmorhage is low. On the other hand, full heparisation might cause severe morbidity, and $\mathrm{CPB}$ might initiate consumptive coagulopathy and profound systemic inflammatory reaction [28]. Off pump cardiopulmonary bypass is an alternative when it comes to coronary artery lesions [16,22,25]. Establishing CPB in arrested patients or patients in deep haemorrhagic shock is not favourable for the outcome [6]. It could be debated whether or not the aorta should have been cross-clamped in our patient during repair of the left ventricular wall and coronary bypass surgery, but the ECG changes and the suspicion of pre-existing ischemia due to sustained pre-operative hypoperfusion, persuaded us to leave the aorta unclamped in this particular case.

Peroperative fluorescent angiography is a reliable tool to identify suspect coronary artery involvement peroperatively either caused by the injury itself or the surgical procedure [15], unfortunately this technique was not available at our OR. Cardiac stabbings might lead to initially unidentified additional injuries which become apparent first several weeks to years later $[8,18]$. One study with a large series of patients report that these injuries seldom need surgical treatment [5]. There is consensus that echocardiographic assessment should be provided during the hospital stay $[5,11]$.

On admission to the ED, our patient was given a high Glasgow coma score (GCS), yet post-operatively was found to have had a cerebral injury. Unfortunately, the patient was foreign, and despite speaking, nobody could assess his verbal response adequately. Furthermore, he received an intravenous injection of Ketalar a few minutes after admission, following which he needed assisted manual ventilation and was no longer able to communicate. The initial GCS was later reconsidered and probably the patient suffered from major hypoxia in the pre-hospital phase. Nevertheless the patients with lower GCS have poor outcome, Asensio still reports a high mortality rate $(27 \%)$ for patients with Glasgow Coma Scale $>8$ [2]. However, in an emergency room thoracotomy material GCS was found to be a predictor of survival, despite none of the patients had a score $>7$ [29]. In our patient, it is possible that CPB might have caused cerebral injury by embolization or by giving an insufficient cerebral perfusion pressure. With pre-existing cerebral damage, the standard perfusion pressure during $\mathrm{CPB}$ in our patient (mean arterial pressure $50-60 \mathrm{mmHg}$ ) might not have been high enough to meet the needs of the brain already damaged by hypoperfusion.

Patients with a simple penetrating cardiac injury might be successfully managed without a cardiac surgeon present $[2,3]$. However, repair of a severe wound of the left ventricle and the complications that can arise will require the surgical skills of a cardiac surgeon, as demonstrated in the present study and the likelihood of survival will be considerably increased by the immediate availability of a cardiac surgical service. The cases where initial tamponade was managed at a lower trauma care center with further transfer for definite surgery, witness of general surgeon`s competence of the initial management of these patients $[13,28]$. In our level I trauma center, a cardiothoracic surgeon in the trauma team has been practiced for decades and we believe provides optimal management of patients with penetrating cardiac trauma.

\section{Conclusions}

We present a complicated case of a young male patient with a chest stab wound who served the trauma team both diagnostic and treatment challenges. We provide the reader a review of literature of the last 15 years publications on penetrating cardiac injury, focusing on stab wounds. Our patient suffered a stroke which origin could be multigenetic, prehospital hypoperfusion, air emboli due to major lung injury and/or insufficient perfusion pressure or microemboli during the cardiopulmonary bypass. The patient in our study survived with minor sequelae due to coordinated work of the trauma team in charge. In conclusion, if the patient with a penetrating stab wound in the heart is not obviously dead on arrival, an attempt for cardiac repair should be done with or without $\mathrm{CPB}$.

Competing interests

The authors declare that they have no competing interests.

\section{Authors' contribution}

Both authors were operating surgeons regarding the presented patient case. $\Pi$ provided the idea of the article. $M-L K$ drafted the initial manuscript while 
both authors worked on improvement and refining of the final manuscript. Both authors read and approved the final manuscript.

Received: 23 January 2012 Accepted: 24 April 2012 Published: 28 May 2012

\section{References}

1. Asensio JA, Petrone P, Pereira B, Pena D, Prichayudh S, Tsunoyama T, et al: Penetrating cardiac injuries: a historic perspective and fascinating trip through time. J Am Coll Surg 2009, 208:462-472.

2. Asensio JA, Berne JD, Demetriades D, Chan L, Murray J, Falabella A, et al: One hundred five penetrating cardiac injuries: a 2-year prospective evaluation. J Trauma 1998, 44:1073-1082.

3. Clarke DL, Quazi MA, Reddy K, Thomson SR: Emergency operation for penetrating thoracic trauma in a metropolitan surgical service in South Africa. J Thorac Cardiovasc Surg 2011, 142:563-568.

4. Molina EJ, Gaughan JP, Kulp H, McClurken JB, Goldberg AJ, Seamon MJ: Outcomes after emergency department thoracotomy for penetrating cardiac injuries: a new perspective. Interact Cardiovasc Thorac Surg 2008, 7:845-848.

5. Tang AL, Inaba K, Branco BC, Oliver M, Bukur M, Salim A, et al: Postdischarge complications after penetrating cardiac injury: a survivable injury with a high postdischarge complication rate. Arch Surg 2011, 146:1061-1066.

6. Baker JM, Battistella FD, Kraut E, Owings JT, Follette DM: Use of cardiopulmonary bypass to salvage patients with multiple-chamber heart wounds. Arch Surg 1998, 133:855-860.

7. Bar I, Papiashvili M, Jeroukhimov I, Muhanna AY, Alzaanin AA: Strategies in the management of penetrating cardiac trauma based on 14 surviving patients from a strife-ridden area. Ind J Thorac Cardiovasc Surg 2009, 25:23-26.

8. Barbosa FM, Quiroga JM, Otero AE, Girela GA: Aortic valve regurgitation with aorto-right ventricular fistula following penetrating cardiac injury. Interact Cardiovasc Thorac Surg 2011, 13:653-654.

9. Bowley DM, Saeed M, Somwe D, Boffard KD, Naidoo K, Davis SC: Off-pump cardiac revascularization after a complex stab wound. Ann Thorac Surg 2002, 74:2192-2193.

10. Burack JH, Kandil E, Sawas A, O'Neill PA, Sclafani SJ, Lowery RC, et al: Triage and outcome of patients with mediastinal penetrating trauma. Ann Thorac Surg 2007, 83:377-382.

11. Carr JA, Buterakos R, Bowling WM, Janson L, Kralovich KA, Copeland C, et al: Long-term functional and echocardiographic assessment after penetrating cardiac injury: 5-year follow-up results. J Trauma 2011, 70:701-704.

12. Chughtai TS, Gilardino MS, Fleiszer DM, Evans DC, Brown RA, Mulder DS: An expanding role for cardiopulmonary bypass in trauma. Can J Surg 2002, 45:95-103.

13. Claassen CW, O'connor JV, Gens D, Sikorski R, Scalea TM: Penetrating cardiac injury: think outside the box. J Trauma 2010, 68:E71-E73.

14. Comoglio C, Sansone F, Boffini M, Ribezzo M, Rinaldi M: Nail gun penetrating injury of the heart mimicking an acute coronary syndrome. Int J Emerg Med 2010, 3:135-137.

15. Desai ND, Moussa F, Singh SK, Chu P, Fremes SE: Intraoperative fluorescence angiography to determine the extent of injury after penetrating cardiac trauma. J Thorac Cardiovasc Surg 2008, 136:218-219.

16. Fedalen PA, Bard MR, Piacentino V III, Fisher CA, McCarthy JR, Schina MJ Jr, et al: Intraluminal shunt placement and off-pump coronary revascularization for coronary artery stab wound. J Trauma 2001, 50:133-135.

17. Fulton JO, Brink JG: Complex thoracic vascular injury repair using deep hypothermia and circulatory arrest. Ann Thorac Surg 1997, 63:557-559.

18. Hibino N, Tsuchiya K, Sasaki H, Matsumoto H, Nakajima M, Naito Y: Delayed presentation of injury to the sinus of valsalva with aortic regurgitation resulting from penetrating cardiac wounds. J Card Surg 2003, 18:236-239.

19. Ito H, Saito S, Miyahara K, Takemura H, Sawaki S, Matsuura A: Traumatic ventricular septal defect following a stab wound to the chest. Gen Thorac Cardiovasc Surg 2009, 57:148-150.

20. Jodati A, Safaei N, Toufan M, Kazemi B: A unique nail gun injury to the heart with a delayed presentation. Interact Cardiovasc Thorac Surg 2011, 13:363-365.
21. Kang $N$, Hsee $L$, Rizoli S, Alison P: Penetrating cardiac injury: overcoming the limits set by Nature. Injury 2009, 40:919-927.

22. Karin E, Greenberg R, Avital S, Aladgem D, Kluger Y: The management of stab wounds to the heart with laceration of the left anterior descending coronary artery. Eur J Emerg Med 2001, 8:321-323.

23. Kurimoto Y, Kano H, Yama N, Nara S, Hase M, Asai Y: Out-of-hospital cardiopulmonary arrest due to penetrating cardiac injury treated by percutaneous cardiopulmonary support in the emergency room: report of a case. Surg Today 2007, 37:240-242.

24. Lau CK, Chin HF, Ong FH, Eng KH: Emergency department thoracotomy for pericardiac tamponade. Singapore Med J 2008, 49:e382-e384

25. Moore FO, Berne JD, Turner WF, Villarreal DH, McGovern T, Rowe SA, et al: Off-pump coronary artery bypass is an alternative to conventional cardiopulmonary bypass when repair of traumatic coronary artery injuries is indicated. Am Surg 2007, 73:296-298.

26. Nwiloh J, Edaigbini S, Danbauchi S, Aminu MB, Oyati A: Arrow injury to the heart. Ann Thorac Surg 2010, 90:287-289.

27. O'Connor J, Ditillo M, Scalea T: Penetrating cardiac injury. J R Army Med Corps 2009, 155:185-190.

28. Parra MW, Costantini EN, Rodas EB, Gonzalez PJ, Salamen OJ, Catino JD, et al: Surviving a transfixing cardiac injury caused by a stingray barb. Thorac Cardiovasc Surg 2010, 139:e115-e116.

29. Seamon MJ, Shiroff AM, Franco M, Stawicki SP, Molina EJ, Gaughan JP, et al: Emergency department thoracotomy for penetrating injuries of the heart and great vessels: an appraisal of 283 consecutive cases from two urban trauma centers. J Trauma 2009, 67:1250-1257.

30. Sugiyama G, Lau C, Tak V, Lee DC, Burack J: Traumatic ventricular septal defect. Ann Thorac Surg 2011, 91:908-910.

31. Tasdemir K, Evereklioglu C, Kaya MG: Transient cortical blindness and successful recovery after coronary bypass surgery. Acta Cardiol 2011, 66:661-664.

32. Toda K, Yoshitatsu M, Izutani H, Ihara K: Surgical management of penetrating cardiac injuries using a fibrin glue sheet. Interact Cardiovasc Thorac Surg 2007, 6:577-578.

33. Topal AE, Celik Y, Eren MN: Predictors of outcome in penetrating cardiac injuries. J Trauma 2010, 69:574-578.

34. Topaloglu S, Aras D, Cagli K, Ergun K, Deveci B, Demir AD, et al: Penetrating trauma to the mitral valve and ventricular septum. Tex Heart Inst J 2006, 33:392-395.

35. Topcuoglu MS, Poyrazoglu HH, Yaliniz H: A unusual case of right lung and right atrio-inferiocaval injury caused by stabbing. Thorac Cardiovasc Surg 2009, 57:248-249.

36. Gwely NN, Mowafy A, Khalaf S, Amer S, Hamza U, El-Saeed M: Management of stab wounds of the heart: analysis of 73 cases in 10 years. Thorac Cardiovasc Surg 2010, 58:210-214

37. Hougen HP, Rogde S, Poulsen K: Homicide by firearms in two Scandinavian capitals. Am J Forensic Med Pathol 2000, 21:281-286.

38. Pahle AS, Pedersen BL, Skaga NO, Pillgram-Larsen J: Emergency thoracotomy saves lives in a Scandinavian hospital setting. J Trauma 2010, 68:599-603.

39. Braathen B, Bøen A, Thorsen T, Tønnessen T: Gunshot through the left ventricle. Resuscitation 2009, 80:615-616.

40. Carr CS, Alkhafaji S, Alkhulaifi A, Carr CS, Alkhafaji S, Alkhulaifi AM: Penetrating cardiac nail gun injury. BMJ Case Rep 2009, 2009:bcr2006040121.

41. Grieve P: Cardiac perforation secondary to a fractured rib sustained in a ram attack in New Zealand: a review of ovine fatalities and an important lesson regarding the severely injured chest. N Z Med J 2006, 119:U2315.

doi:10.1186/1749-7922-7-17

Cite this article as: Kaljusto and Tønnessen: How to mend a broken heart: a major stab wound of the left ventricle. World Journal of Emergency Surgery 2012 7:17. 